\title{
BOOKS AS INFORMATIONAL ARTEFACTS
}

\author{
Kurmo Konsa, Tiiu Reimo
}

\begin{abstract}
The article focuses on the model based on the information levels of books as artefacts and the importance of information levels for preservation strategy. The historical and museological approaches to books as objects will be discussed. Books are artefacts just like any other objects made, modified, or used by human beings. Different authors have presented various approaches for describing the information architecture of artefacts. This study is based on a three-level model, according to which three different information levels are identified: structural information or structural properties; functional information or functional properties; context and the object's relationship to it. Preservation is not a passive activity from the point of view of the information structure of the artefact. While choosing preservation strategies it is essential to consider the information structure of the artefact, especially when using information reformatting technologies, which create a new object with a specific information structure (photocopies, microforms, digitisation, etc.). The preservation of artefacts presumes the prior identification of the set of information to be preserved.
\end{abstract}

Keywords: artefact, information, models, book, preservation

At first glance, there is nothing surprising about books - they are ordinary and often inconspicuous additions to our daily lives. The word "book" is so rooted in spoken language that we usually do not even notice when it is used. Even in electronic environments, "e-book" is the best term that has been found for conventional text presentations. Yet books are paradoxical objects. Outwardly they are material objects, but they contain texts immaterial creative works by authors - which can exist in different physical forms. ${ }^{1}$

The advances in digital technology have resulted in texts being less and less connected to their physical shapes, including books as objects. Today

\footnotetext{
The article was prepared with the assistance of grant no 8205 from the Estonian Science Foundation.

1 Ülo Matjus, "Raamat kui asi," Kloostrist internetini [Eesti Raamatu Aasta lõpukonverentsi ettekanded 5.-6. aprillil 2001 Pärnus], ed. by Tõnu Tender (Tartu: Eesti Raamatu Aasta Peakomitee, 2011), 91-100.
} 
the production of books has been digitised to the point that the only nondigital object is the final product of this process - the book itself. ${ }^{2}$ To a great extent today's world is textual - in addition to book texts, these include all kinds of electronic e-mails, Wikis, blogs, tweets, social networks, etc. Digital texts are also connected to material objects, such as DVDs, hard drives, flash drives, display screens, etc., but the relationship of the text to the material carrier is less important than with traditional documents books or photos. Compared to earlier information carriers, digital texts vary to a greater degree and are unstable. At the same time, these characteristics make it simpler to process and distribute texts. ${ }^{3}$ However, even if a researcher is interested primarily in the text, one cannot ignore the fact that there is a close relationship between the text (content) and its outward appearance (physical artefact), and they impact each other. ${ }^{4}$ The technologies used affect not only the transmission, preservation and utilisation of texts, but also their content. Thus, texts recorded in books, as well as the outward appearance of books, represent a certain culture; and they record various kinds of information. During the last few decades, in connection with topical issues related to the preservation of cultural heritage, interest in the material presentation forms of texts has increased because every text needs to be expressed in the form of an artefact - be it a bound book, manuscript, document or image on a computer screen.

The broad-based spread of digital texts has prompted people to write about the "death of the book," but this is clearly a case of overdramatising the situation. Never have more ordinary books been published than today and books are still the main means of presenting knowledge and ideas, as well as recording memories and creating different fictionary worlds. The Internet has created new advertising and trading opportunities for books

\footnotetext{
Miha Kovač, Never mind the web: here comes the book (Oxford: Chandos, 2008), 2-3. Luke Tredinnick, Digital information culture: the individual and society in the digital age (Oxford: Chandos Publishing, 2008), 68-71.

4 Gerard Genette, Paratexts: thresholds and interpretation (Cambridge: Cambridge University Press, 1997), 1-15; Katherine N. Hayles, "Translating media: why we should rethink textuality," Yale Journal of Criticism, 16:2 (2003), 263-290 (276); G. Thomas Tanselle, "The recording of American books and the British bibliographical tradition (1985)," Literature and artifacts (Charlottesville: The Bibliographical Society of the University of Virginia, 1998), 157-185; G. Thomas Tanselle, "Textual criticism and deconstruction (1990)," Literature and artifacts (Charlottesville: The Bibliographical Society of the University of Virginia, 1998), 203-235 (220-221). The connections between handwritten books and their content, based on phenomenological aspects, have been examined by Meelis Friedenthal, Tallinna Linnaarhiivi Tractatus moralis de oculo, Dissertationes theologiae Universitatis Tartuensis, 13 (Tartu: Tartu Ülikooli Kirjastus, 2008).
} 
(amazon.com), and broadened the market for used and rare books. ${ }^{5}$ Books are certainly one of the most popular artefacts, and more of them have survived from previous centuries than any other artefact. Thus, for instance, if we disregard buildings and coins, books are the most numerous artefacts that have survived from the Middle Ages. ${ }^{6}$ The ability to economically convey, preserve and distribute information in the form of books has been perfected. ${ }^{7}$ Electronic reading devices provide readers with many advantages, such as the possibility for word searches, electronic bookmarks, text enlargement, etc., but being dependent on a device for reading does not make a book as familiar and convenient as one that is printed on paper and bound. Even e-book readers increasingly resemble books. ${ }^{8}$

With the growth of the digital medium, interest in books as objects has also increased. If at first this was caused by a fear that book culture is dying out, then later interest started focusing on highlighting the characteristics of the print and digital mediums, and on their comparison.

The examination of books as a part of material culture is related to various branches of research - to sociology, economic and social history, and the theory of literature, as well as bibliography, the history of books, philosophy and anthropology. The aim of this article is to introduce the treatment of books as artefacts in the history of books and to present an informational model for books. This model can form the basis for various theoretical treatments of books as objects, and help to make practical decisions related to preservation.

\section{The history of books as a field of research: theoretical approaches}

The scientific research of books as objects began in the eighteenth century. At first the focus was on describing the first printed books - the incunabula. In order to attribute books without knowing where or when they

\footnotetext{
5 Scott E. Casper, Joanne D. Chaison, Jeffrey D. Groves, "The once and future book," Perspectives on American book history: artifacts and commentary, ed. by Scott E. Casper, Joanne D. Chaison, and Jeffrey D. Groves (University of Massachusetts Press, in association with the American Antiquarian Society, 2002), 435-440 (438).

6 Christopher De Hamel, "Books and society," The Cambridge history of the book in Britain, II: 1100-1400, ed. by Nigel Morgan and Rodney M. Thomson (Cambridge: Cambridge University Press, 2008), 3.

7 Manfred Breede, The brave new world of publishing: the symbiotic relationship between printing and book publishing (Oxford: Chandos, 2008), 1.

8 Catherine C. Marshall, Reading and writing the electronic book (Princeton: Morgan \& Claypool, 2010), 3-10).
} 
were printed, or the name of the printer, the production processes preserved in the books themselves had to be examined, including the format, layout, collation, labelling of the signatures, sheets and pages, typefaces and decorative typographic elements. All these elements help to determine when and where a book was produced. The concept of "descriptive" bibliography was first adopted by Henry Bradshaw (1831-1886), head of the Cambridge University Library. ${ }^{9}$ The goal of a descriptive bibliography was to describe the "ideal copy" - the book in the form that the publisher and printer had planned to publish it. As precise a description of the components of the book as possible allowed the surviving copies to be identified and the various printing versions and editions to be determined. These research methods are still employed today when describing old publications. In the early twentieth century, English and American bibliographers started using the concept "critical bibliography," which, in addition to describing the book's structure, also examined the materials and processes related to its production, starting with the paper and ink, and ending with the printing process and binding. The leading researchers in this "new school of bibliography"10 were Ronald B. McKerrow", Walter Wilson Greg ${ }^{12}$ and Fredson Bowers ${ }^{13}$. According to Greg, "Critical bibliography is the science of the material transmission of literary texts." ${ }^{14}$ The French researcher Gerard Genette had a similar approach to books, and in his book "Seuils" (1987) focused on the research of "paratexts". ${ }^{15}$ He defines paratexts as the auxiliary texts that surround the main text, such as epigraphs, subtitles, illustrations, forewords and epilogues, the author's biography and photo, errata etc., which help to bring the book

\footnotetext{
9 A very good survey of Bradshaw's bibliographical activities is provided by the following: Paul Needham, The Bradshaw Method: Henry Bradshaw's contribution to bibliography (Chapel Hill: University of North Carolina, 1988).

10 For a survey see, for example, G. Thomas Tanselle, "A description of descriptive bibliography (1992)," Literature and artifacts, ed. by G. Thomas Tanselle (Charlottesville: The Bibliographical Society of the University of Virginia, 1998), 137 (127-156); 137; R. B. McKerrow, An introduction to bibliography for literary students (Oxford: Clarendon press, 1927) was the main critical bibliography textbook until the 1970 .

11 McKerrow, An introduction to bibliography for literary students.

12 Walter Wilson Greg, A bibliography of the English printed drama to the restoration, I (London: The Bibliographical Society, 1939).

13 Fredson Bowers, Principles of bibliographical description (Princetown: Princetown University Press, 1949).

14 Walter Wilson Greg, "What is bibliography?" Transactions of the Bibliographical Society, 12 (1914), 39-53 (48).

15 Gerard Genette, Seuils (Paris: Le Seuil, 1987).
} 
to the reader. Of the more famous researchers that treat books as objects, G. Thomas Tanselle definitely deserves mention. ${ }^{16}$

The bibliographic approach to books broadened in the 1960s and 1970s, when Donald Francis McKenzie (1931-1999) introduced the concept of "the sociology of texts". In his essay called "The sociology of a text: orality, literacy and print in early New Zealand," which provided the name for his theoretical approach, McKenzie stressed that attention should be paid not only to the content of the text, but also to its outward appearance as a material object, its creation and reception: printed books are a rich combination of signs, each of which has its own history and meaning in the production of a book as a final product. A book as a physical object is the embodiment of its creator's human decisions, which reflect the social conditions in which the book is created. ${ }^{17}$ Simultaneously with the approach to books as artefacts, another trend developed that viewed books in a social context as the executor of certain functions in society and the generator of social changes. The most noteworthy representatives of this trend were the French historians Lucien Febvre and Henri-Jean Martin, whose work called "Lapparition du livre" (The coming of the book), which appeared in 1958, opened the way to the socio-historical treatment of the history of books. ${ }^{18}$ The Polish researchers Karol Głombiowski (1913-1986) and Krzysztof Migoń (b. 1939) developed the functional theory of bibliography, ${ }^{19}$ which includes the history of the production, distribution and use of books, i.e. the communication that takes place via books, as a subject for study that they tried to relate to processes taking place in society. ${ }^{20}$ In the 198 os, the "history of the book" became an independent field of research that Robert Darnton defined in his classic article entitled "What is the history of books?". Based on models used in communications research, Darnton presented a model of a communications circle that included the production, distribution and

\footnotetext{
16 See for example the collection of articles Literature and artifacts (Charlottesville: The Bibliographical Society of te University of Virginia, 1998) and the articles: "The future of primary records," Biblion, 5:1 (1996), 4-32; Texts and artifacts in the electronic era, <http://www.columbiauniversity.org/cu/21stC/issue-3.2/tanselle.html> [accessed 19 February 2014].

17 Donald McKenzie, "The sociology of a text: orality, literacy and print in early New Zealand," The Library, 6:4 (1984), 333-365; Donald McKenzie, The book as an expressive form, The Panizzi Lectures (London: British Library, 1985).

18 Lucien Febvre, Henry-Jean Martin, L’apparition du livre (Paris: Les Éditions Albin Michel, 1958).

19 Karol Głombiowski, "O funkcjonalną koncepcję nauki o książce," Studia o książce, 1, (1970), 5-24; Krzysztof Migoń, Nauka o książce: zarys problematyki (Wrocław: Zakład Narodowy im. Ossolińskich, 1984).

20 Krzysztof Migoń, Nauka o knige (Moskva: Kniga, 1991), 115.
} 
reception of books in order to track the role of texts in society, along with the economic, political and social factors that impact them. ${ }^{21}$ English book historians Thomas R. Adams and Nicolas Barker criticised Darnton's model for focusing excessively on persons and institutions in the development of books at the expense of books as artefacts. They worked out their own model of a book's lifecycle, which includes publication, production, distribution, reception and preservation and is surrounded by four fields of influence: 1) intellectual influences; 2) political, legal and religious influences; 3 ) business interests, and 4) social behaviour and tastes..$^{22}$ Jerome McGann's concept of "the socialisation of texts," which emphasises the materialisation of texts, or the transmission of books as artefacts from immaterial texts in the private sphere (e.g. in the author's head) to materialised texts (books) in the public sphere, also confirms the distancing of the history of books from its focus on literature and text instruction. ${ }^{23}$ Alistair Black, an English historian of library history, places the history of books in the context of information research, seeing the history of books, libraries and reading as a part of the field of research focused on information history. ${ }^{24}$ In recent years, the concepts of material philology, as well as artefactual philology, have cropped up in the course of studying old Icelandic manuscripts, which also focuses on the material side, the origins, owners and utilisation of manuscripts. ${ }^{25}$

David Finkelstein and Alistair McCleery name three revolutionary changes in human communication: the transition from oral communication to written communication; from written texts to printed text; and from printed texts to computer-based texts. ${ }^{26}$ Inevitably, every such transition is accompanied by a partial loss of information, because all the texts that exist in one or another form are never transferred to the new level. The digitisation of written and printed cultural heritage has created the false impression

\footnotetext{
21 Robert Darnton, "What is the history of books?" Daedalus, 111 (1982), 65-83.

22 Thomas R. Adams, Nicolas Barker, "A new model for the study of the book," A potencie of life: books in society, ed. by Nicolas Barker (London: British Library, 1993), 5-43.

23 Jerome McGann, The textual condition (Princetown, NJ: Princetown University Press, 1991).

24 Alistair Black, "Information history," Annual Review of Information Science and Technology, 40 (2006), 441-473 (445).

25 Matthew J. Driscoll, "The words on the page: thoughts on philology, old and new," Creating the medieval saga: versions, variability, and editorial interpretations of Old Norse saga literature, ed. by Judy Quinn and Emily Lethbridge (Odense: Syddansk Universitetsforlag, 2010), 85-102.

26 The book history reader, ed. by David Finkelstein and Alistair McCleery (London and New York: Routledge, 2002), 4.
} 
that the preservation of information is ensured when texts are transferred from one carrier to another. From the viewpoint of the preservation of cultural heritage, this understanding is a simplification, and all the information contained in written or printed books needs to be preserved.

To date, the theoretical approaches to the history of books lack a universal theoretical model for the integrated study of books as objects. The creation of such a model is necessary and topical from the aspect of both information and preservation science.

\section{Books as artefacts and their informational levels}

According to Jürgen Mittelstraß, we all live in "Leonardo's world," an artificial world filled with artefacts produced by people with the help of science and technology. ${ }^{27}$ Artefacts are the material objects created by everyone, starting, for example, with geological samples that are collected (i.e. removed from their original context) and preserved for some definite purpose, and ending with the most complicated technological objects. Communicative artefacts - books, documents, pictures, sound recordings, computer data carriers, etc. - comprise a special group of artefacts, the main function of which is to record and convey information. ${ }^{28}$

Below, we will take a look at artefacts in the informational context, i.e. what information they contain and what information is related to them. This is a fundamental question for information science as well as preservation since this is the basis for developing all the strategies for interpreting and preserving information. We should start with the word "information." This concept is defined in many different ways. Information scientist Michael Buckland differentiates three fundamental ways of using the word "information": 29

1) Information as a process: the process of informing, communication. By informing someone we change their knowledge about something.

2) Information as knowledge: that which is transmitted in the course of informing, the communication process. Knowledge that refers to certain facts, people or events.

\footnotetext{
27 Jürgen Mittelstraß, "Science and the environment - challenges, risks, and the future," European Journal of Clinical Pharmacology, 38:1 (1990), 1 (1-4).

28 David M. Levy, Catherine C. Marshal, "Going digital: a look at assumptions underlying digital libraries," Communications of the ACM, 38:4 (1995), 77-84 (78).

${ }_{29}$ Michael K. Buckland, "Information as thing," Journal of the American Society of Information Science, 42:5 (1991), 351-360 (351).
} 
3) Information as an object: an object that information is presented as. Information always appears in the form of some material carrier. This can be a book, document, but also a sound wave (as in speech).

Information as knowledge is immaterial and therefore cannot be measured directly. Knowledge, beliefs and opinions are personal, subjective and conceptual. In order to transmit them, their expression, presentation or description in some physical form is necessary, which is "information as an object". Information systems always deal with artefacts that are created, collected, used and preserved.

Every artefact is essentially an inexhaustible source of information. Different authors have offered various approaches to the description of information related to artefacts. ${ }^{30}$ In the case of communicative artefacts, two main possibilities exist for the description of their information structures. The most widespread and clearest is probably a model in which the information found in a book is divided dichotomically, i.e. the book is treated as being comprised of its content in the broadest sense and as the material carrier of this content. Books are viewed as containers, with texts that can be relocated in other containers without losing any of the information. As Linnar Priimägi writes in his essay "The unbearable lightness of the Renaissance spirit": "Literature does not need books; a book is only a temporary rented apartment for literature; a package of papers that are bound on one edge - a ridiculous object, and yet, a brilliant invention for its convenience."31 Based on the dichotomic model the text or content is abstracted from the artefact, and in most cases, it is asserted that only the text is the preservation object. This dichotomic model is also used as a formal or informal basis for many preservation activities. To a great extent, microfilming, digitisation and other methods for reformatting information are based on this theoretical model.

The reformatting of information for preservation purposes is a widespread strategy used by libraries and archives, although today's technologies also enable the preservation of three-dimensional objects as digital images. In connection with the explosive growth of the importance of digital information in all spheres of society, one can be sure that the

30 Susan M. Pearce, “Thinking about things,” Museums Journal, 85:4 (1986), 198-201; McClung E. Fleming, "Artifact study: a proposed model," Material culture studies in America, ed. by Thomas J. Schlereth (Lanham: Altamira Press, 1982), 162-173.

31 Linnar Priimägi, "Renessansivaimu talumatu kergus," Arkaadia: Eesti Päevalehe kirjanduse ja esseistikalisa, 16 September 2000. 
importance of reformatting information will increase. ${ }^{32}$ Although the dichotomic approach to the infrastructure of some artefacts may be justified, this model is still too simplified to be used as a basis for all preservation activities.

In the case of multi-level models, various information levels are differentiated in the artefact. According to Peter van Mensch's model, three information levels are discerned in the artefacts: ${ }^{33}$

1) structural information or structural properties;

2) functional information or functional properties;

3) context and the object's relationship with the context.

Structural information includes all physical (structural) properties of the object, such as material, construction, design, etc., i.e. all the information that can be perceived by the senses and examined using physical-chemical research methods. Usually the term "object" or "artefact" is used in this context to label the object in the physical sense. The source of the structural information is the artefact itself; for all the following information levels, information from supplementary sources is required.

Books are comprised of very different materials, such as paper, ink, cardboard, glue, leather, etc. Each material in turn has quite a complicated composition and different physical-chemical properties. ${ }^{34}$ Damage processes depend to a great degree on the properties of the materials. The primary material used for producing publications is paper. The composition of paper has changed significantly over time and these changes have had a considerable impact on the aging and durability of paper. Aging also affects other materials used to produce books. ${ }^{35}$ Construction is the way the object is produced and the parts that it is comprised of. The construction of books has also changed significantly throughout history based

\footnotetext{
32 A survey of the newest trends is provided by the articles in the following collections: Digital heritage, ed. by Lindsay MacDonald (Butterworth-Heinemann, 2006) and Lorna M. Hughes, Digitizing collections: strategic issues for the information manager (London: Facet Publishing, 2004).

33 Peter van Mensch, "Methodological museology; or, towards a theory of museum practice," Objects of knowledge, ed. by Susan M. Pearce (London and Atlantic Highlands: Atlone Press, 1992), 141-157; Peter van Mensch, Towards a methodology of museology, dissertation (University of Zagreb, 1992).

34 Carlo Federici, "Methodology and practice of archaeological analysis in the study of book materials," PACT: Revue du groupe européen d'études pour les techniques physiques, chimiques, biologiques et mathématiques appliquées a l'archéologie = PACT: Journal of the European Study Group on Physical, Chemical, Biological and Mathematical Techniques Applied to Archaeology, 12:12 (1985), 261-274.

35 Kurmo Konsa, Arhivaalide ja trükiste säilitamine (Tartu: Kleio, 2008), 46-53.
} 
on the materials that have come into use and the technologies that have been developed, but also because of changes in taste and the demands of users. ${ }^{36}$ Design characterises the appearance of the object, its form, colour, decoration, style, iconography, etc. Objects made of similar materials and constructed similarly may still be designed differently.

Formatting is important in the case of communicative artefacts and this is reflected in the way information is presented, structured and positioned. ${ }^{37}$ The following parts can be differentiated in formatting:

1) the means of expressing information (content): content can be expressed as a text (i.e. a sequence of words), a picture or combination thereof, as data, cartographic material, notations, etc.;

2) the means of presenting information: how the text is positioned, structured, designed, etc.;

3) additions, or indirect information: all kinds of subsequent additions, such as supplemental text, underlining, comments, the owner's markings, etc.

Indirect information is information that is unplanned, which collects in the object during its "lifespan". The amount of such information is not small, since documents and books are quite good at collecting information. Paper is a material with very good absorbent properties; it bonds easily with gases, liquids and solid particles. There are many breaking points and other hidden parts in bindings where objects that have ended up there accidently or intentionally may be preserved for a long time. By using ordinary physical-chemical analytical methods, it is possible to use this type of information for drawing very interesting conclusions. ${ }^{38}$ In the case of many types of artefacts, sound, smell and taste can also be very important structural properties. For instance, in connection with books we can speak of the sound made by turning the pages, the smell of ink characteristic of new books, etc. ${ }^{39}$

\footnotetext{
36 Endel Valk-Falk, Ajastu stiilitunnuste säilitamine konserveerimisel: metoodiline kogumik, I: gooti, renessanss- ja barokkstiil köitekunstis (Tallinn: Eesti Akadeemiline Raamatukogu, 1999).

37 The issues related to the formatting of communicative artefacts have in dealt with in detail in the archival field, see, for example, Dokumendi omadused, <http://www.ra.ee/ abc/index.php?tree_id=37> [accessed 15 September 2013].

38 Jiři Vnouček, "Can we manage to restore medieval books without any loss of information?" 7. Internationaler Graphischer Restauratorentag, 26.-30. August 1991 (Uppsala: Preprint, 1991), 29-34.

39 Gary Frost, "Reading by hand: the haptic evaluation of artists' books," The Bonefolder: an e-journal of the bookbinder and book artists, 2:1 (2005), 3-6, <http://www.philobiblon.
} 
Functional information refers to the use of the artefact. Understandably, each artefact can fulfil various functions. In the case of objects containing documental information, their communicative function is usually the primary one. These objects are created in order to convey ideas, knowledge, etc. We read books primarily for their content and in this sense, book texts are functional information. Texts that are interpreted as being functional can be called compositions, as Virve Sarapik has done ${ }^{40}$, or simply as the content of books. Functional information is also contained in books as objects. Often this is an aesthetic function. Books are treated as works of art; they are used, for instance, to design interiors, etc. ${ }^{41}$ The semiotic examination of objects focuses on the meaning that alludes to things outside of the object, such as events, abstract ideas, meanings, etc. Objects mean something; they function as certain signs and/or texts. This function can be defined as symbols. Books have a strong symbolic function that is clearly visible through their content or as physical objects. ${ }^{42}$ Owning certain books indicates the owner's level of education, wealth, status and prestige. Therefore these objects also fulfil a value-related function by providing information about the owner, the user's wealth, status, self-perception, interests, etc. The metaphysical function refers to the relationship with the supernatural world, which is attributed to many artefacts, including books. In many religions, such as Christianity and Islam, books are symbols of divine revelation. For Islamic mystics, the book is a metaphor for the entire universe. ${ }^{43}$

The functional information of artefacts is actually very complex and comprises a complicated structure that is constantly changing. A book's function is different for the author, the publishing house, the printing house, the bookstore, at home on the reading table and at a rare book exhibition. To a great extent, the functions of an artefact are connected to its context, which comprises the third component of the object's infrastructure.

com/bonefolder/vol2no1contents.htm $>$ [accessed 18 February 2014]; The smell of a book, $<$ http://www.topics-mag.com/edition19/smells/book.htm> [accessed 19 February 2014].

40 Virve Sarapik, Keel ja kunst (Tallinn: Underi ja Tuglase Kirjanduskeskus, 1999), 9-10.

${ }^{41}$ See, for example, Juri Lotman,"Kunstikooslus kui olmeruum," Kultuurisemiootika: tekst - kirjandus - kultuur (Tallinn: Olion, 1990), 304-316.

${ }^{42}$ Régis Debray, "The book as symbolic object," The future of the book, ed. by G. Nunberg (California: University of California Press, 1996), 139-151 (141, 143-145).

${ }^{43}$ See for example: Jack Tresidder, Sümbolid: illustreeritud teejuht kujundite, ikoonide ja embleemide maailma (Tallinn: Kirjastus Ilo, 2002), 191; Juan Eduardo Cirlot, $A$ dictionary of symbols (Routledge, 1990), 31. About books as magical objects, see Richard Kieckhefer, Forbidden rites: a necromancer's manual of the fifteenth century (Sutton Publishing, 1997), 4-5. 
The word "context" is derived from the Latin word contextus, which means a connection or joining. In this model, this means the relationship between the artefact and its environment. Context can be described as a system with two dimensions - a material (physical) and conceptual one. The physical context includes all the other objects to which the book is related during production and, thereafter, utilisation. ${ }^{44}$ Considering the physical context is very important in the case of collections. In various collections, one and the same artefact can carry different meanings or the value of an object may be influenced by the fact that it is part of a collection. As a conceptual system, context can be understood as the cultural and social environment related to the artefact. In the case of books, the important aspects of the context can be, for example, the economy, commerce, the organisation of information in the society, descriptive systems for books, production, tools, technology, division of labour, worldview, art, etc. Context can be related to the history of the object. Often it is not the objects themselves that are important but the people to whom they have belonged and the historical events that they have participated in.

\section{Changes in the informational content of artefacts}

The amount of an object's informational content is not constant, but is continually changing. Objects that are treated as artefacts are the result of a historical process and, therefore, "biographies" of the objects to be preserved are required in order to choose the most relevant preservation strategy. Therefore, in addition to the data categories of the synchronous list provided above, the historical states of the objects must be determined.

In the "biography" of an artefact, it is possible to differentiate three states: the conceptual state, factual state and actual state. The life story of an artefact starts with an idea conceived by its producer, which, in turn, is related to the author's conceptual context, i.e. specific culture. There are no artefacts as such; there are only objects from a specific culture and specific moment in time. The conceptual state of an artefact is a potential object that is still an idea. The subsequent states of an artefact refer to an object that has already been realised. The factual state reflects the object immediately after the completion of the production process. In many cases, the factual state is only a hypothetical construction, since it is not possible to

44 A very interesting treatment of the mutual development of books and their storage methods can be found in Henry Petroski, The book on the bookshelf (New York: Knopf, 1999). 
precisely determine the moment when an object was completed: the producer may make changes; the object may be left unfinished; or the object may be finished by someone else. Throughout its "lifespan" the information structure of the object changes and the object reaches us in its actual state. The actual state includes both the initial information (primary data) and the information that is lost and added during its use, deterioration and conservation (secondary data). It is important to understand that an object in its factual state is not identical to the same object at some later moment in time. It may be the same book or document, but as time passes, its set of physical-chemical properties, functions and meanings is no longer identical, nor is the context in which the book was after it was completed. In time, both the structural and functional properties, as well as the context of the object change; we see the sum of all these changes at the time that we examine the object in its actual state.

The informational content of artefacts is impacted by both physicalchemical and social processes. Of the natural processes, the most important are undoubtedly the constant deterioration and aging of the materials. All materials deteriorate over a shorter or longer period of time, i.e. they age. A whole series of physical-chemical processes take place, which result in a change in the chemical composition of the materials and the worsening of the mechanical properties. The aging process is irreversible, although its speed may vary significantly. Materials differ when it comes to the speed of aging and their reactions to changes in the environmental conditions. The damage processes of artefacts depend significantly on the chemical-physical properties of the materials, which are determined by the raw materials and technological processes used to produce the particular materials. The life story of the materials, including the storage conditions in the past, have a great impact on their utilisation in the present. A series of environmental factors, such as temperature, moisture content, light, pollutants, vibration, magnetic fields, and biological damage, significantly affects the condition of the object. ${ }^{45}$ Generally, aging is understood to mean the reduction of the informational level. Sometimes the informational value of an object can actually increase in the course of aging. The damage may add documentary value by reflecting some important events, or it may also add aesthetic value; like for instance, the patina, crackling or aging of the varnish layer in paintings.

The greatest impact on the informational content of artefacts results from various human activities. Any utilisation of the artefacts changes

45 Konsa, Arhivaalide ja trükiste säilitamine, 123-145. 
them. Objects wear when they are used; they suffer various damage; objects may be partly or totally destroyed. Changes in ideology often cause artefacts to be destroyed or modified. For instance, the destruction of countless books starting with the destruction of the famous Library of Alexandria in $47 \mathrm{BC}$ and ending with the destruction of the Iraq National Library in $2003 .{ }^{46}$

The functions of an object change just like its structural properties. As a rule, the utilitarian value of an object is reduced by its physical, technological and psychological obsolescence. When an object loses its practical value, it is often thrown away or recycled as raw material. Considerably more interesting is the situation where the reduction in the utilitarian value of the object increases its aesthetic and symbolic value. For instance, some commodities start being treated as works of art, whereas both their meaning and function are modified. Books that we can no longer read often become works of art. The modification of the artefacts' functions may also cause changes in their structural properties.

\section{The information structure and preservation of artefacts}

The information structure of artefacts is not simple because the various informational levels are interconnected and impact each other. From the viewpoint of an artefact's information structure, preservation is not a passive activity. The fact that an artefact ends up in a memory institution (a library, archive or museum) modifies its functional and contextual information, not to mention its conservation or informational reformatting. When choosing a preservation strategy, it is fundamentally important to consider the information structure of artefacts. This is especially true when using reformatting technologies (photocopying, creation of microforms, digitisation, etc.), in the course of which a new object with a specific information structure is created.

When preserving communicative artefacts, the following questions arise: what do we ultimately wish to preserve; is it the book's content, the book as an artefact, or a way of using the information, i.e. all information objects have an intrinsic means of interpretation and utilisation. Today, information reformatting methods are widely used in the preservation

46 About the destruction of books, see, for example: Leo Lowenthal, "Caliban's legacy," Publishing Research Quarterly, 4:3 (1998), 74-83; Daniel Christopher Sarefield, Burning knowledge: studies of book burning in ancient Rome, dissertation (The Ohio State University, 2004); Lucien X. Polastron, Books on fire: the destruction of libraries throughout history (Thames and Hudson, 2008). 
of communicative artefacts. Often these are the simplest, least expensive and readily available solutions for the preservation of library and archival materials. These methods are the only conceivable possibilities for materials that can no longer be preserved because of their deterioration or if their condition makes their use impossible.

People have known since ancient times that phenomena can be presented and represented in various ways. This is a situation in which an object is presented via another object. The second object is a representation of the first one. The technologies that are used can vary to a great degree. If the object (original) and its representation are sufficiently alike, we refer to it as a copy or reproduction. ${ }^{47}$ If we make a photo of the page of a book, this is a copy. A photo of a church is a representation, not a copy of the church. After all, the copy of a building is a three-dimensional structure that is as similar to it as possible. The method for copying communicative artefacts is generally called reformatting. The following methods can be used to reformat information:

- electrographic duplication (photocopying);

- photography (creating an image on photographic materials, incl. microfilming);

- digitisation (creating a digital image).

All these methods have their advantages and disadvantages, and depending on the aim of the reformatting, various methods can be used. There can be a number of different aims for the reformatting of information, which to a greater or lesser degree are connected to the preservation of collections, as well as to simplifying and increasing their use.

Information may be reformatted for the following reasons:

- preservation;

- usage

- preservation and usage.

The copies that are produced are also differentiated on the basis of their purpose. A replacement copy is a copy of the original or a copy produced by the information reformatting of an original that is not available at the institution, is unusable, or has been destroyed by accident or on purpose (if

47 A copy or reproduction is a document obtained by copying the original. Visually similar to the original it is a different material object. An exact copy or replica is a copy of an object that is as similar as possible to the original in regard to its appearance, materials and production methods. For example, facsimile editions of books are exact copies. 
the original was damaging other archival documents), and which replaces the original. The purpose of a replacement copy may be both preservation and utilisation. Replacement copies may also be produced for exhibitions or off-site use. A user copy (access copy, service copy) is a copy produced by reformatting the information, the purpose of which is to ensure that this information is available for wider use, while also reducing the damage that may be caused to the original by frequent use. In the case of digital user copies, a very important purpose is expanding the utilisation of the information through online services. Copies that are made to facilitate information searches (e.g. adding a photo to a catalogue) can also be considered to be user copies. In many cases, the information in these copies can be even more easily utilised than the information in the original. An example would be reading a digitally processed copy of a manuscript written in faded ink or the text in the bottom layer of a palimpsest. A preservation copy (archival copy, safety copy) is a copy produced by reformatting the information to ensure that the information is preserved and usable even if the original should be destroyed or damaged. A characteristic of the information reformatting process is the transfer of part of the information in the artefact to another artefact. There are two important aspects from the viewpoint of the artefacts' information structure. On the one hand, in the course of the information reformatting process, part of the information is recreated. If a microfilm is made of a book, the part of the information that is transferred to the photo emulsion is recreated there in the material sense. The book remains, but it is recreated in the layer of emulsion. New information is created, which to a certain specific extent, corresponds to the original.

On the other hand, the idea of this entire process is a kind of renewal of the object - making it new again (even if it affects only a part of the information connected to the object). In the case of the previous example of microfilm, we create an object that is "newer" and therefore ensures that the transferred information will endure. A new object is created by the information reformatting process, which shares certain traits with the original, but which clearly does replace all the aspects of the original. A communicative artefact is created, which, to a certain extent, coincides with the information content of the original object. Generally, information reformatting does not involve all the information connected to the original object. Only part of the information is transferred. Which part depends, on the one hand, on the technology being used (what can be transferred) and, on the other hand, on the preservation decision (what is 
to be preserved). Physical artefacts and their digital reproductions can be clearly differentiated since the information is changed and modified during the information reformatting process. The information structure of the object should be considered when choosing preservation methods. If it is important to preserve the information about the structural properties of the artefact, the artefact itself must be preserved. To preserve the functional and contextual information, supplemental information should also be collected and preserved along with the artefact.

\section{Summary}

The interest in books as artefacts is nothing new. The scientific examination of books as objects already began in the eighteenth century. Books written by hand, as well as printed books, are artefacts and, as such, contain a great variety of information. Besides the textual content, they also contain information about their production history and therefore also the history of a specific society. They are part of the material culture of their time and carry the social context of their era. This information is important from the viewpoint of the history of books, and also affects the meaning of texts. Text reception is largely dependent on its presentation. Books, just like other informational artefacts, are always read as a whole. All the elements - paper, page dimensions and shape, placement of the text, typeface, binding material and design - mean something to the reader. All these details play a role in the reading process.

The information structure of artefacts is not simple since information levels are interconnected and impact each other. When designing a preservation strategy, it is important to decide what amount of information we want to preserve. The preservation of artefacts assumes that the quantity of information to be preserved has been determined in advance. Fundamental changes have taken place in preservation science during the late twentieth century. Since its development at the end of the eighteenth century, traditional scientific preservation has been based on the structural properties of artefacts. Today, the objects to be preserved are increasingly valued as the carriers of functional and contextual information. The development of the right strategy for the preservation of cultural heritage assumes that all the informational levels of books as artefacts are taken into account. 
Kurmo Konsa (b. 1965) is Associate Professor at the Department of Archival Studies at the University of Tartu, and Professor of Conservation at Tartu Art College.*

Tiru Reimo (b. 1953) is Professor of Book Sciences at Tallinn University.**

\section{KOKKUVÕTE: Raamat kui informatsiooniline artefakt}

Teaduslik huvi raamatu kui artefakti vastu sai alguse juba 18. sajandist. Käsikirjalised ja trükitud raamatud sisaldavad peale tekstilise sisu väga mitmesugust informatsiooni, mis annab teavet nende valmistusajaloo kohta. Nad on osa oma aja materiaalsest kultuurist ja kannavad ajastu sotsiaalset konteksti. Selline informatsioon on oluline raamatuajaloo seisukohalt, samas mõjutab see ka tekstide tähendust. Teksti retseptsioon sõltub suuresti selle esitusest. Raamatut loetakse, nagu iga teistki informatsioonilist artefakti, alati tervikuna. Kõik selle elemendid - paber, lehtede mõõtmed ja kuju, teksti asetus, kirjatüüp, köite materjal ja kujundus - tähendavad lugeja jaoks midagi, kõik need detailid mängivad lugemisprotsessis oma osa.

Artefakti informatsiooniline struktuur ei ole lihtne, kuna erinevad infotasandid on omavahel seotud ja mõjutavad üksteist. Säilitamisstrateegia kujundamiseks on oluline otsustada, milline on see infohulk, mida me tahame säilitada? Artefaktide säilitamine eeldab säilitatava infokogumi eelneva määratlemise. Säilitamisteadus on 20. sajandi lõpukümnenditel teinud läbi suured ja põhimõttelised muutused. Traditsiooniline teaduslik säilitamine on alates oma tekkest 18. sajandi lõpus tuginenud artefaktide struktuursetele omadustele. Tänapäeval väärtustatakse säilitatavaid objekte üha enam kui funktsionaalse ja kontekstuaalse informatsiooni kandjaid. Kultuuripärandi säilitamiseks õige strateegia kujundamine eeldab raamatu kui artefakti kõigi informatsioonitasandite arvesse võtmist.

\footnotetext{
* Correspondence: Institute of History and Archaeology, University of Tartu, Ülikooli 18, 50090 Tartu, Estonia. E-mail: Kurmo.Konsa@ut.ee

** Correspondence: Institute of Information Studies, Tallinn University, Narva mnt 25, 10120 Tallinn, Estonia. E-mail: Tiiu.Reimo@tlu.ee
} 